\title{
ASSESSMENT OF THE SACCULAR FUNCTION IN CHILDREN WITH SPASTIC CEREBRAL PALSY
}

\author{
Received July 2, 2014
}

Our investigation was designed to assess the saccular function of the vestibular system upon postural control dysfunction amongst children with spastic cerebral palsy (CP) using recording of cervical vestibular evoked myogenic potentials (cVEMPs), as well as to compare such findings with those in healthy subjects. Sixty two children (aged 7-12 years) were enrolled and assigned into two groups. There were 31 cases of spastic CP with the functional levels of I or II according to the Gross Motor Function Classification System in the patient group and 31 aged-matched healthy children as controls. The examined parameters were the latencies of the $\mathrm{P}_{13}$ and $\mathrm{N}_{23}$ waves, $\mathrm{P}_{13}-\mathrm{N}_{23}$ peak-to-peak amplitude, amplitude asymmetry ratio (AAR) and the cVEMP threshold. The cVEMP responses were recorded in $93.5 \%$ of cases in the $\mathrm{CP}$ group and in all healthy subjects. Only $51.6 \%$ of the CP-group cases were within the normal AAR spectrum range. There were significant differences between the two groups with regard to the $\mathrm{N}_{23}$ wave latency $(P<0.001), \mathrm{P}_{13}-\mathrm{N}_{23}$ wave amplitude $(P<0.001)$ and cVEMP threshold $(P<0.05)$. The significant difference in the cVEMP measured values between the $\mathrm{CP}$ cases and healthy controls may be attributed to a motor development delay and deficits in the vestibulo-collic reflex pathway. Our findings suggest that cVEMP recording may be considered an auxiliary tool for the assessment of the vestibular system in children with spastic CP. Such a test is expected to help more adequate planning for interventions.

Keywords: cervical vestibular evoked myogenic potential (cVEMP), children, cerebral palsy, spasticity, vestibular function, saccula.

\section{INTRODUCTION}

Cerebral palsy (CP) is characterized by motor dysfunctions resulting from non-progressive lesions in the fetal or infant developing brain [1]. The above dysfunction of $\mathrm{CP}$ is often accompanied by disturbances in sensation [2], cognition, communication, perception, behavior, and/or seizure disorders [1]. Meanwhile, the condition is known to be the most common cause of physical disability with a prevalence of approximately 2 per 1000 live births $[3,4]$. "The Surveillance of Cerebral Palsy in Europe" (SCPE) classifies this condition based on the anatomic distinction (unilateral and bilateral) and predominant

\footnotetext{
${ }^{1-4}$ University of Social Welfare and Rehabilitation Sciences, Tehran, Iran ( ${ }^{1}$ Department of Occupational Therapy, ${ }^{2}$ Department of Audiology, ${ }^{3}$ Department of Ergonomics, ${ }^{4}$ Pediatric Neurorehabilitation Research Center). ${ }^{5}$ Social Determinants of Health Research Center, University of Social Welfare and Rehabilitation Sciences, Tehran, Iran.

Correspondence should be addressed to S. A. Hosseini

(e-mail: alihosse@gmail.com).
}

neuromotor abnormality (spastic, dyskinetic, or ataxic) [1]. Spastic CP is the most abundant type reported $[3,4]$. Postural control dysfunction (the subject's inability to maintain balance) is an integral part of the problem in children with $\mathrm{CP}$; this imposes noticeable activity limitation and participation restrictions [5]. The vestibular system plays an important role in the postural control, while postural dysfunction has dissimilar mechanisms in different $\mathrm{CP}$ subtypes $[6,7]$. The role of the vestibular system in postural control as well as integration of inputs from both sensory and motor systems has been extensively discussed in the literature $[6,7]$. Exploring the underlying mechanisms of balance disorders in CP may result in an adequately planned remediation approach and optimized treatment interventions $[8,9]$.

Together with the conventional electrophysiological assessments, there are special tests available to assess the function of the vestibular system. Several studies have thus far been conducted on adult subjects using electronystagmography (ENG), caloric tests, and 
rotator chair tests. Meanwhile, notable limitations in such tests make them unsuitable for use in children; this is why these tests are not widely used in clinical practice [8-12]. The cervical vestibular evoked myogenic potential (cVEMP) is one of the clinical tests used to assess balance disorders. This test assists the examiner to evaluate the saccular function of the vestibular system and to assess the inferior vestibular nerve and the vestibulo-spinal tract $[8,9]$. This test may only be used to assess the sacculo-collic reflex in healthy newborns and children [13-16], but also to determine further fundamental parameters $[11,16,17]$. Responses can then be compared between children with impairments and healthy subjects [18-22]. The cVEMP is and EMG responses of the sternocleidomastoid muscle (SCM) following a high-level acoustic stimulation of the saccula via the vestibulo-collic reflex pathway. The typical response is characterized by the first major positive peak $\left(\mathrm{P}_{13}\right.$, or $\left.\mathrm{P}_{1}\right)$ wave and the first negative peak following $\mathrm{P}_{13}$ known as the $\mathrm{N}_{23}$ $\left(\mathrm{N}_{1}\right)$ wave $[10,11]$. The cVEMP derives in the saccular macula of the inner ear, moves to the Scarpa's ganglion through the inferior vestibular nerve, brainstem lateral vestibular nucleus, and descending medial vestibulospinal tract, and then ultimately terminates at the level of motor neurons of the SCM $[8,9]$. To identify the causes of balance impairments and to design effective and precise interventions with proper measurements, the clinical assessment of the vestibular system seems to be crucial $[8,9]$.

To the best of our knowledge, only one particular report described findings on the vestibular system in children with CP using the cVEMP $[23,24]$. The aims of our study were to examine the saccular function of the vestibular system in children with CP (7-12 years) using cVEMP, and to compare these responses with those in healthy age-matched control subjects.

\section{METHODS}

Participants: This study enrolled 31 children with spastic CP (CP group) and 31 age-matched healthy children (control group). Cases in the CP group were recruited consecutively from those who referred to the rehabilitation centers of the University of Social Welfare and Rehabilitation Sciences (Tehran), while healthy controls were selected from the elementary school students. Inclusion criteria for both groups were the chronological age of 7-12 years, lack of any visual disorder (including nystagmus and strabismus), no history of hearing problems based on the parent's report, normal results of behavioral audiometry [25] and tympanometry [26], and a normal range of motion in the neck. For the CP group, the diagnosis of spastic CP was confirmed by a neurologist. The CPgroup subjects were included based on their ability to understand verbal instructions and functional level of I or II according to the "Gross Motor Function Classification System" (GMFCS). Exclusion criteria for both groups were uncontrolled epilepsy, subject's limited behavioral cooperation, and a history of congenital abnormalities in the head and neck.

Techniques. The GMFCS is a tool developed to determine the best level of the child's abilities in the gross motor function in children with CP [27]. This tool focuses on sitting, transferring, mobility, and walking. According to the GMFCS, the walking ability in children older than 4 years is classified into 5 levels (namely, level I, walks independently in and outdoor; level II, walks with minimal limitations; level III, walks using a hand-held mobility device; level IV, self-mobility with limitations, possibly requiring powered mobility, and level $\mathrm{V}$, : transported in a manual wheelchair) [27]. The interrater reliability of the GMFCS has been reported as excellent (generalizability coefficient $\mathrm{G}=0.93$ ) and its testretest reliability as high $(G=0.79)$ [28]. In our investigation, the GMFCS assessment was done by an experienced occupational therapist of the rehabilitation center.

The two-channel cVEMP test using an Eclips EP25, version 4.3 set (Inter-acoustic, Denmark) was performed by an expert audiologist at the MollaSadra Dizziness treatment Center (Tehran). The EMG-controlled recording done by this version of inter-acoustic cVEMP was considered an advantage, since such protocol only allows data collection once the participant provides a desirable muscle tone. Moreover, the patient EMG monitor feature assisted the participants to maintain adequate muscle contraction in real time. The applied EP25 Interacoustic setup made it possible to automatically calculate the amplitude asymmetry ratio (AAR) upon recording.

According to the cVEMP guideline [10], each participant sat upright in a comfortable chair with a back and an armrest in a quiet room upon recording. The subjects' feet were resting on the floor, and the arms were placed on the armrest. The sites for electrode montage were cleaned with an alcohol wipe. A none-inverting electrode was placed on the 
upper third of the belly of the SCM $[10,16,29]$. The inverting electrode was positioned on the edge of the sternum, and a ground electrode was set on the forehead $[10,16,29]$. In order to capture the desired responses from each ear, the child was required to flex the head approximately $30 \mathrm{deg}$ forward and rotate it approximately $30 \mathrm{deg}$ toward the contralateral side, while looking at the fixed picture (set $>2 \mathrm{~m}$ from the eyes) on the wall $[10,29]$. Every participant was trained to keep his /her head in this position for $1 \mathrm{~min}$. Responses from the next ear could be similarly acquired. To record cVEMP, 200 responses to airconducted $500-\mathrm{Hz}$ short tone burst stimuli presented monaurally with rarefaction polarity via an insert receiver were averaged with a stimulation rate of 7.1 $\mathrm{sec}^{-1}$ at the $95 \mathrm{~dB}$ HL intensity level. According to this method, the stimulus was set at a rise-and-fall time of $2 \mathrm{msec}$ and a plateau time of $0 \mathrm{msec}$. In order to ascertain the reproducibility of signal acquisition, measurements were repeated twice from each side [1422, 25]. The measured cVEMP parameters were the latency, amplitude of the two positive-negative waves $\left(\mathrm{P}_{13}-\mathrm{N}_{23}\right)$, and cVEMP threshold, as well as the AAR $[10,11]$. The AAR between the two ears allowed us to compare the vestibular function between the left and right ear, which was calculated as follows:

Amplitude asymmetry ratio $=(\mathrm{Ar}-\mathrm{Al}) /(\mathrm{Ar}+\mathrm{Al})$. $100 \%$,

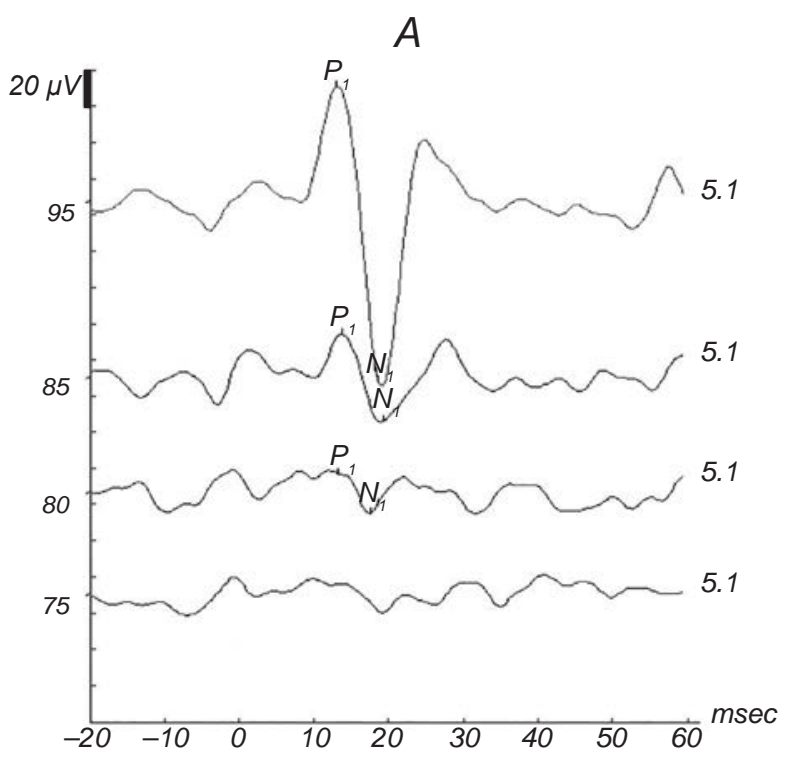

where Ar is the amplitude at the right ear and $\mathrm{Al}$ is that at the left ear; values higher than $36 \%$ were considered abnormal [30].

The EMG amplitude was set at the $50-60 \mu \mathrm{V}[10$, 29]; the responses were bandpass-filtered (20-2000 $\mathrm{Hz})$ and amplified $(\times 5000)$. The electrode impedances were maintained below $5 \mathrm{k} \Omega$.

Statistical Analysis. Data were analyzed using the SPSS version 15. Based on Kolmogrove-Smirnov, we used the Student's $t$-test to compare cVEMP parameters between the $\mathrm{CP}$ group and controls within the normal AAR range. In each group, the cVEMP parameters were analyzed with regard to gender using the Mann-Whitney $U$ test. $P<0.05$ represented the statistical significance.

\section{RESULTS}

The mean \pm s.d. of age in the control group (13 girls/ 18 boys) was $8.78 \pm 1.52$ years. Participants in the CP group ( 8 girls $/ 23$ boys, age $8.77 \pm 1.52$ years) were of different types of limb spasticity. Fifteen children had unilateral (hemiplegia) CP, while 16 children had bilateral (11 quadroplegic and 5 diplegic) spastic CP (Table 1). The cVEMP responses of all subjects in the control group were found to be bilateral within the normal AAR range (Fig. 1), while only 21 children

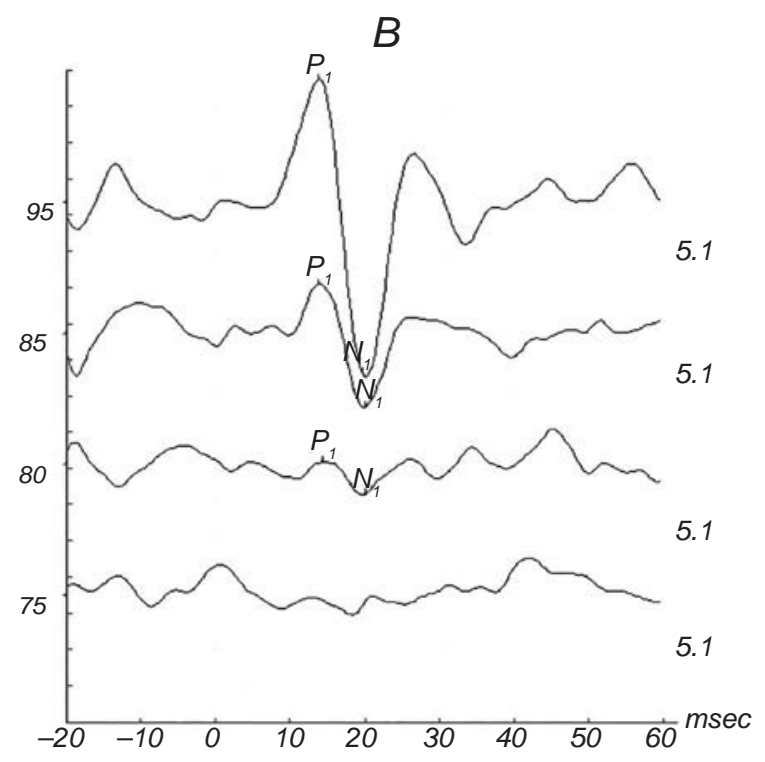

F i g. 1. Cervical vestibular evoked myogenic potentials recorded in a healthy child (bilateral normal responses at the threshold level). Stimulation of the right (A) and left (B) ear. Vertical scale) Intensity of stimulation, dB nHL.

P и с. 1. Шийні вестибулярні викликані міогенні потенціали (відведення у здорової дитини з білатеральними нормальними реакціями на пороговому рівні). 
T a b l e 1. Characteristics of children with $C P$

Т а б л и ц я 1. Характеристики дітей, що страждали на церебральний параліч

\begin{tabular}{|c|c|c|c|c|c|c|}
\hline Subjects, no. & Age (years, months) & Gender & Type of the response & Type of CP & GMFCS**, level & Affected side \\
\hline 2 & 9.02 & Boy & Normal AAR & Unilateral & I & Left \\
\hline 4 & 7.01 & Girl & Abnormal AAR & Bilateral & II & Left \\
\hline 5 & 9.00 & Boy & Abnormal AAR & Bilateral & II & Right \\
\hline 6 & 9.00 & Boy & Normal AAR & Bilateral & II & Right \\
\hline 9 & 7.01 & Girl & Normal AAR & Unilateral & II & Left \\
\hline 10 & 10.06 & Boy & Normal AAR & Bilateral & II & Left \\
\hline 11 & 7.01 & Boy & Normal AAR & Bilateral & II & Left \\
\hline 12 & 9.01 & Boy & Normal AAR & Unilateral & $\mathrm{I}$ & Left \\
\hline 13 & 9.04 & Boy & Normal AAR & Bilateral & II & Left \\
\hline 18 & 8.05 & Girl & Normal AAR & Unilateral & $\mathrm{I}$ & Left \\
\hline 19 & 10.04 & Boy & Normal AAR & Unilateral & I & Left \\
\hline 20 & 10.09 & Boy & Normal AAR & Unilateral & I & Left \\
\hline 21 & 9.07 & Boy & Abnormal AAR & Bilateral & I & Right \\
\hline 22 & 10.03 & Girl & No response & Bilateral & $\mathrm{I}$ & Left \\
\hline 23 & 7.00 & Girl & No response & Unilateral & II & Left \\
\hline 24 & 9.04 & Boy & left response & Bilateral & $\mathrm{I}$ & Right \\
\hline 25 & 7.00 & Girl & Right response & Unilateral & II & Left \\
\hline 26 & 7.00 & Girl & left response & Bilateral & II & Right \\
\hline 27 & 8.06 & Boy & left response & Unilateral & II & Right \\
\hline 28 & 9.02 & Boy & Right response & Unilateral & II & Left \\
\hline
\end{tabular}

F o o t n o t e: *AAR, amplitude asymmetry ratio; **GMFCS, Gross Motor Function Classification System

showed bilateral cVEMP responses in the CP group (Fig. 2). Normal and abnormal AAR spectrum was seen in 16 and 5 subjects of the CP group, respectively. The cVEMP responses of 8 children in the CP group were unilateral (3 in the right and 5 in the left ear), while the response was totally absent in two children with CP. All participants were appropriately cooperating upon recording. The average test time was 10 and 14 min for the control and CP groups, respectively.

Means \pm s.d. for the cVEMP threshold level and latency of the $\mathrm{P}_{13}-\mathrm{N}_{23}$ waves, as well as their amplitude in each group, are demonstrated in Table 2. Data analysis revealed normal distributions of the variables in both groups.

The cVEMP threshold was shown to be significantly higher in the CP-group subjects of the normal AAR range $(n=16)$, as compared to the control group $(P<0.05)$. The mean value for the left-ear $\mathrm{P}_{13}-\mathrm{N}_{23}$ wave amplitudes in the $\mathrm{CP}$ group within the normal AAR range was significantly smaller than that in the control group $(P<0.001)$. However, such a difference was not found to be statistically significant for the right ear. The mean latency of the $\mathrm{N}_{23}$ wave in the CP group within the normal AAR range was significantly shorter for both ears, as compared to the control group $(P<0.001)$. Meanwhile, the two groups did not show any significant difference with regard to the mean latency of the $\mathrm{P}_{13}$ wave (Table 3). Further analysis revealed no significant difference in the cVEMP parameters between girls and boys $(P=0.31)$.

\section{DISCUSSION}

Findings of our report are expected to provide insights into the significance of the saccular function assessment 

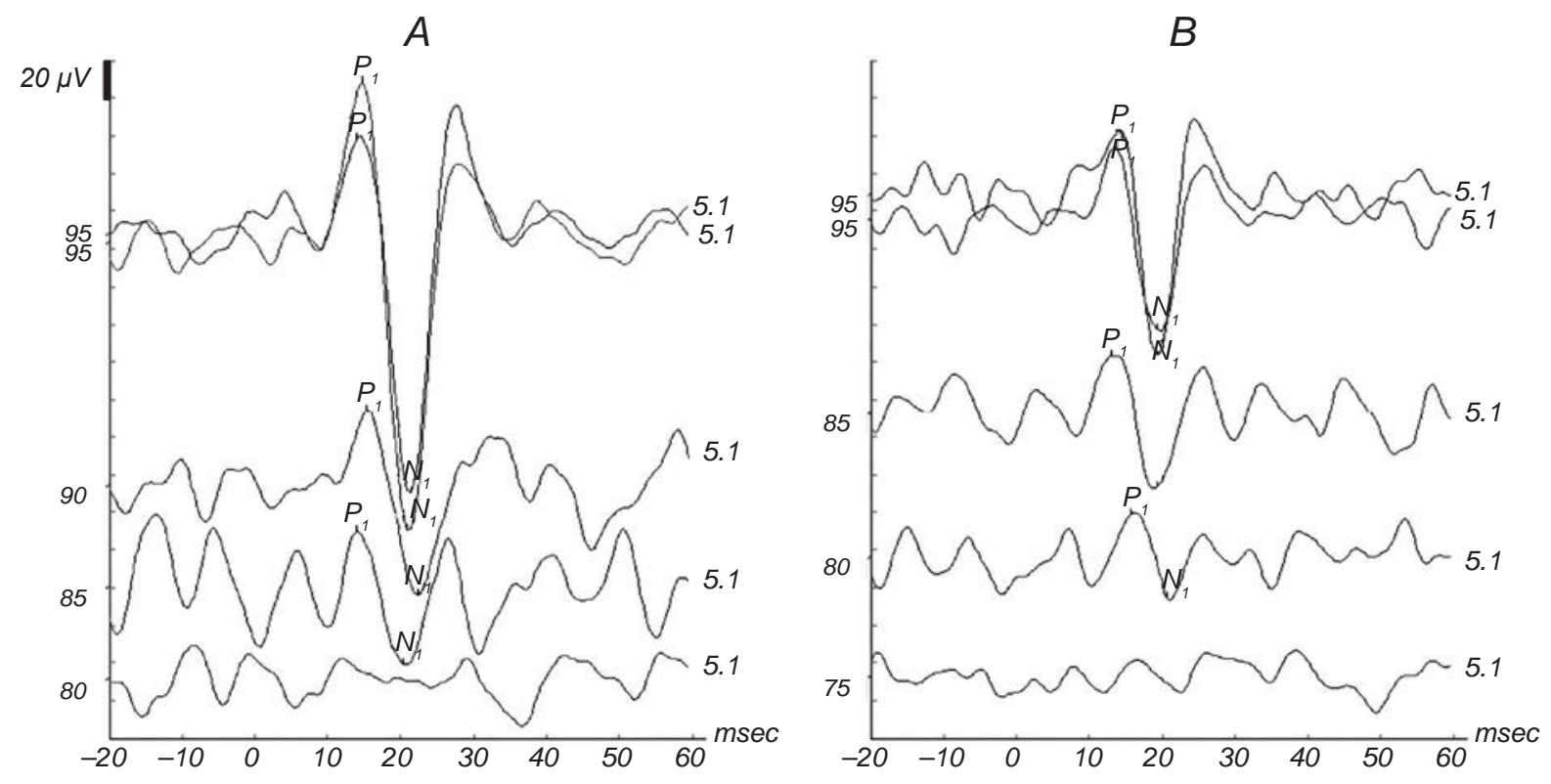

F i g. 2. Cervical vestibular evoked myogenic potentials recorded in a child with CP (bilateral abnormal responses at the threshold level). Designations are similar to those in Fig. 1.

P и с. 2. Шийні вестибулярні викликані міогенні потенціали (відведення у дитини з церебральним паралічем із білатерально порушеними реакціями на пороговому рівні).

T a b l e 2. cVEMP parameters at stimulations of the right and left ears in the studied groups

T а б л и ц я 2. Параметри шийних вестибулярних викликаних міогенних потенціалів (сVЕМР) при стимуляції правого та лівого вуха в обстежених групах

\begin{tabular}{|c|c|c|c|c|c|c|}
\hline Parameters & \multicolumn{2}{|c|}{$\mathrm{CP}$ group } & \multicolumn{2}{|c|}{ Healthy group } & \multicolumn{2}{|c|}{$\mathrm{P}$ value } \\
\hline $\mathrm{P}_{13}$ latency (msec) & $\begin{array}{c}14.72 \pm 2.19 \\
(n=24)\end{array}$ & $\begin{array}{c}15.24 \pm 1.58 \\
(n=26)\end{array}$ & $\begin{array}{c}15.04 \pm 1.22 \\
(n=31)\end{array}$ & $\begin{array}{c}15.04 \pm 1.18 \\
(n=31)\end{array}$ & 0.49 & 0.57 \\
\hline $\mathrm{N}_{23}$ latency $(\mathrm{msec})$ & $\begin{array}{c}20.42 \pm 2.37 \\
(n=24)\end{array}$ & $\begin{array}{c}21.17 \pm 1.56 \\
(n=26)\end{array}$ & $\begin{array}{c}23.74 \pm 1.72 \\
(n=31)\end{array}$ & $\begin{array}{c}23.93 \pm 1.23 \\
(n=31)\end{array}$ & $<0.001$ & $<0.001$ \\
\hline Threshold (dB nHL) & $\begin{array}{c}87.50 \pm 5.89 \\
(n=24)\end{array}$ & $\begin{array}{c}88.07 \pm 5.49 \\
(n=26)\end{array}$ & $\begin{array}{c}80.97 \pm 6.34 \\
(n=31)\end{array}$ & $\begin{array}{c}78.06 \pm 4.22 \\
(n=31)\end{array}$ & $<0.001$ & $<0.001$ \\
\hline AA R (\%) & & $\begin{array}{c}22.52 \pm 16.76 \\
(n=21)\end{array}$ & $\begin{array}{c}14.09 \pm 10.47 \\
(n=31)\end{array}$ & & & 0.03 \\
\hline
\end{tabular}

F o o t n o t e: Means \pm s. d. values are shown; AAR, amplitude asymmetry ratio

using the cVEMP in children with spastic CP. The results presented proposed the feasibility of cVEMP recording in children with this pathology. This finding is inconsistent with a few earlier available reports $[23,24]$. In contrast to our findings, Kaga et al. stated that cVEMP may not be used to assess the vestibular function in children with $\mathrm{CP}$ due to PelizaeusMerzbacher disease [23, 24]. Nevertheless, they suggested that cVEMPs might be used as an indicator of hyper- or hypo-tonicity of muscles in these children $[23,24]$. In our study, $93.5 \%$ of children with CP demonstrated cVEMP responses. Such inconsistency between our findings and that of Kaga et al. may partly be attributed to study limitations including a small sampling size ( 3 boys), lacking comprehensive data about the subjects (e.g., extent of functional disability), 
T a b l e 3. Comparison of the cVEMP parameters between the CP group with the normal amplitude ratio range and the control group

T а б л и ц я 3. Порівняння параметрів шийних вестибулярних викликаних міогенних потенціалів (сVEMP) у групі дітей із церебральним паралічем, що мали нормальне значення відношення амплітуд, та в контрольній групі

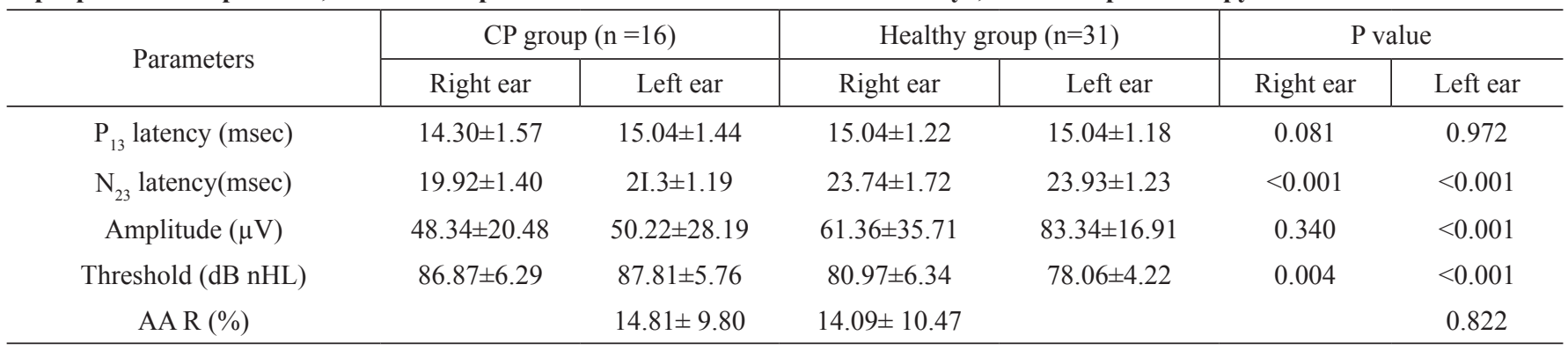

F o o t n o t e: Designations are similar to those in Table 2.

and the type of cVEMPs recording (e.g., stimulation type, instrument, and subjects' position). In principle, Pelizaeus-Merzbacher disease is not considered CP in the strict meaning. This is a dysmyelinating disorder of the brain during the prenatal period caused by gene mutation [23]. Moreover, this research recruited cases with definite diagnosis of CP, while this has not been the case in earlier reports. We ensured that our protocol for cVEMP recording was aligned with the corresponding international guideline [10].

During our cVEMP evaluation, two participants in the CP group showed no response. Similarly to this observation, some studies on healthy children or children with hearing impairments have reported the absence of the cVEMP response possibly due to an incomplete myelination of the sacculo-collic reflex [13], disorders in brainstem axon myelination, incompetent synaptogenesis and formation of central synaptic connections [31], as well as the immaturity of the auditory brainstem [16]. In this sense, sound stimulation of the saccula could produce inhibitory postsynaptic potentials in the cervical flexor motoneurons through inhibitory interneurons in the vestibular spinal pathway $[6,8,11]$. The pathogenesis of the sacculo-collic reflex pathway impairment in $\mathrm{CP}$ is not clear. Meanwhile, magnetic resonance imaging (MRI) demonstrated white matter lesions as the predominant deficiencies in these children [32, 33]. Pathological changes in the cortical structures [2] and/or impairments of afferent axons or vestibulospinal axons of such a pathway can possibly be documented. We speculate that the absence of the cVEMP response in some children with CP might be related to bilateral dysfunction of the saccular system and the corresponding neural afferents (cVEMP reflex pathway). As such, the unilateral responses might be attributed to unilateral dysfunction of the saccula and related afferents, as well as the level of the gross motor function and the type of CP. Six cases revealing unilateral responses were in level II according to the GMFCS, and four of them were of unilateral spastic CP. Since we had the unilateral spastic CP as the prevalent type in our study $(48.1 \%)$, we expected to observe notable differences in the AAR between CP and control groups (Table 2). Nevertheless, since the cases in the $\mathrm{CP}$, were predominantly impaired at the left $(61.3 \%)$ rather than at the right side $(33.7 \%)$, significant differences in the cVEMP parameters between the two groups were at the left ear. These results might indicate that the laterality of the involved central nervous system may affect the cVEMP parameters. Having noted this, further studies with other types of CP in different age groups are needed to confirm the applicability of cVEMP in children.

This study also provided some novel data with regard to the comparison of the $\mathrm{N}_{23}$ and $\mathrm{P}_{13}$ wave parameters between the two groups. Childrens with $\mathrm{CP}$ and a normal AAR range, exhibited a shorter latency of the $\mathrm{N}_{23}$ wave, a smaller amplitude of the $\mathrm{P}_{13}-\mathrm{N}_{23}$ waves, and remarkably higher threshold, as compared to the respective indices in the control group. However, our results revealed no significant difference in the $\mathrm{P}_{13}$ wave latency. Evidence supports that the cVEMP threshold is affected by the total sensitivity of the vestibular end organs and the neural relays $[9,11]$. Along these lines, several authors have demonstrated that a higher cVEMP threshold response in children with severe-to-profound hearing loss is due to the dysfunction of the saccula $[19,22]$. Therefore, the higher threshold response among children with 
$\mathrm{CP}$ might be linked to deficits in the firing rate in the saccula, since the related neurons would require more intense stimuli to generate effective responses. Nevertheless, such a notion needs further research to be proven correctly.

With respect to the shorter latency of the $\mathrm{N}_{23}$ wave in the $\mathrm{CP}$ group, it was shown that the $\mathrm{P}_{13}$ wave latency is related to the frequency, intensity, and type of stimulation, while the latency of the $\mathrm{N}_{23}$ wave largely depends on the nerve conduction velocity and fiber inclination [34]. Several authors have indicated that the latency of these components are related to age $[11,13,17,31]$, motor development delay [35], neck length [34], and developmental changes and myelination of the sacculo-collic reflex pathway, as well as to developmental changes in the pathway between the saccula and SCM [20]. Normally, the vestibular function response in healthy children is formed within the first 6-12 months of life and becomes gradually matured when one reaches the age of 15 years. This process in children with CP is, however, very sluggish, and the vestibular system may not attain the desired function until the 15-year age. On the other hand, the severity of sensory system impairments [7, 36] and sensory-motor developmental delay can leave an impact on the maturation of vestibular receptors (e. g., saccular ones) and cVEMP parameters [35]. Considering the age-matched groups and the identical method used, the significant shortening of the $\mathrm{N}_{23}$ wave latency was unexpected and contradictory with the existing knowledge. Justification of this controversy may depend on further studies.

According to the present findings, the $\mathrm{P}_{13}-\mathrm{N}_{23}$ waves among the CP group in the normal range showed a shorter amplitude, as compared to controls. Based on the literature, the tonocity and activation degree of the SCM, as well as the stimulation level may leave an impact on the $\mathrm{P}_{13}-\mathrm{N}_{23}$ wave amplitude. The diminished amplitude of these waves demonstrates desynchronization of neural firing and attenuation of the conduction velocity along fibers of the pathway responsible for the cVEMP response [9, 11]. Other studies have proposed that the diminished amplitude of the $\mathrm{P}_{13}-\mathrm{N}_{23}$ waves among healthy newborns is attributed to a smaller muscle effort upon head and neck rotation [16] and the paucity of nerve fibers in the inferior vestibular nerve [16]. In children with myelomeningocele, this phenomenon is caused by the SCM hypertrophy, abnormality of the SCM tone, and an abnormal cervical posture [20]. Children with spastic $\mathrm{CP}$ show various deficits in the modulation of muscular responses, such as excessive antagonistic muscle co- activation (muscle inhibitory system), hypertonicity, weakness, inappropriate timing of muscle activation, lack of voluntary movements [37], decreased neuronal supply of the reflex pathways, and a decreased number of nerve fibers [38]. Considering the same SCM tone with a full range of motion in the neck, the attenuated $\mathrm{P}_{13}-\mathrm{N}_{23}$ wave amplitude in this study is thought to result from developmental changes in the pathway between the saccula and SCM, a deficit in the muscle inhibitory system, and motor unit firing impairment.

Similarly to many other investigations, our study is subjected to a number of limitations. These limitations were the dearth of knowledge in this area and the lack of further clinical tests adapted for use in children. More studies on different types of CP, various GFMCS functional levels, and different age groups are recommended. In addition, investigation of the utility of the other vestibular clinical tests together with proprioceptive and functional balance testing in children with CP is suggested.

Thus, results of our investigation indicate that cVEMP recording may be used to assess the saccular function in children with spastic CP. Significant differences in the cVEMP parameters between children with spastic CP and healthy controls were found. Such differences may be related to deficits in the vestibulocollic reflex pathway, motor development delay, and neuromuscular dysfunctions. The cVEMP may be considered a helpful tool from both research and clinical aspects. This can be an effective tool used to diagnosing and determining the neural structure involvement, localization of the lesion in children with $\mathrm{CP}$, and the lesion extent. Moreover, it may provide useful information leading to better rehabilitation planning. The optimized planning is expected to improve postural control with a determined stimulation pattern (linear or spinning) and result in a better sensory organization. Further comprehensive studies are required to distinguish the function of other parts of the vestibular system.

Acknowledgment. This study was a part of the first author's (N. Akbarfahimi) thesis to obtain the PhD degree in occupational therapy. The authors would like to appreciate all participants, their parents, and the Molla-Sadra Dizziness Treatment Center staff for their invaluable contribution to this work.

All participants were informed in detail about the experimental process. The ethical protocol of this study was based on the Declaration of Helsinki and respective international ethical norms. The written informed consent was signed by all participants and their parents. 
The authors, N. Akbarfahimi, S. A. Hosseini, M. Rassafiani, N. Rezazadeh, F. Tabatabai Ghomsheh, S. Shahshahani, and M. Karimlou, declare that there were no conflicts of any kind relating to commercial or financial relations, relations with organizations or persons, which could in any way be associated with the investigation, and to the interrelationship of the coauthors of the article.

\section{Н. Акбарфахімі', С. А. Хоссейні ${ }^{1}$, М. Рассаф'яні ${ }^{1}$, Н. Реза- заде ${ }^{l}$, Ф. Табатабаї Гомшех ${ }^{l}$, С. Шахшахані ${ }^{2}$, М. Каримлу ${ }^{3}$ \\ ОЦІНКА САКУЛЯРНОЇ ФУНКЦІЇ У ДІТЕЙ ЗІ СПАСТИЧ- НИМ ДИТЯЧИМ ЦЕРЕБРАЛЬНИМ ПАРАЛІЧЕМ}

${ }^{1}$ Університет наук про соціальний захист та реабілітацію, Тегеран (Іран).

${ }^{2}$ Педіатричний дослідний нейрореабілітаційний центр при Університеті наук про соціальний захист та реабілітацію, Тегеран (Іран).

\footnotetext{
${ }^{3}$ Науково-дослідний центр соціальних детермінант охорони здоров'я при Університеті наук про соціальний захист і реабілітацію, Тегеран (Іран).
}

P е 3 ю м е

Метою нашого дослідження були оцінка сакулярної функції вестибулярної системи при постуральній дисфункції у дітей, що страждають на дитячий церебральний параліч (ЦП), 3 використанням відведення шийних вестибулярних викликаних міогенних потенціалів (cVEMP) та порівняння відповідних результатів із такими у здорових обстежених дітей. 62 дитини (вік сім-12 років) були розділені на дві групи (31 дитина зі спастичною формою ЦП при функціональних рівнях I та II відповідно до системи класифікації загальних моторних функцій та 31 здорова дитина відповідного віку, що складали групу контролю). Визначали наступні параметри: латентні періоди хвиль $\mathrm{P}_{13}$ та $\mathrm{N}_{23}$, амплітуди цих хвиль, амплітуду від піку до піку коливань $\mathrm{P}_{13}-\mathrm{N}_{23}$, коефіцієнт асиметрії хвиль (AAR) та поріг cVEMP. Істотні cVEMP були зареєстровані в 93.5 \% випадків групи ЦП та в усіх здорових дітей. Тільки у $51.6 \%$ дітей групи ЦП значення AAR відповідали нормальному діапазону цього індексу. Середні величини латентного періоду $\mathrm{N}_{23}$-хвилі, міжпікової амплітуди $\mathrm{P}_{13}-\mathrm{N}_{23}$ і порогу виникнення cVEMP у групах ЦП i контролю вірогідно розрізнялися $(P<0.001, P<0.001$ та $P<0.05$ відповідно). Істотна відмінність виміряних параметрів cVEMP у групах ЦП та здорових дітей може бути пов'язана із затримкою моторного розвитку та дефектністю вестибуло-двогорбикового рефлексу. Наші дані свідчать про те, що відведення cVEMP може бути цінним допоміжним прийомом при функціональній оцінці вестибулярної системи у дітей зі спастичним ЦП. Вірогідно, даний тест може допомогти адекватніше планувати відповідні реабілітаційні заходи.

\section{REFERENCES}

1. P. Rosenbaum, N. Paneth, A. Leviton, et al., "A report: The definition and classification of cerebral palsy April 2006," Dev. Med. Child Neurol., Suppl., 109, 8-14 (2007).

2. I. Kolker, "Hearing function and auditory evoked potentials in children with spastic forms of cerebral palsy," Neurophysiology, 36, No. 4, 270-275 (2004).

3. D. Christensen, K. Van Naarden Braun, N. S. Doernberg, et al., "Prevalence of cerebral palsy, co-occurring autism spectrum disorders, and motor functioning: Autism and developmental disabilities monitoring network, USA, 2008," Dev. Med. Child Neurol., 56, 59-65 (2014).

4. S. Marret, C. Vanhulle, and A. Laquerrier, " Pathophysiology of cerebral palsy," Handbook Clin. Neurol., 111, 169-176 (2012).

5. M. Ferdjallah, G. F. Harris, P. Smith, and J. J. Wertsch, "Analysis of postural control synergies during quiet standing in healthy children and children with cerebral palsy," Clin. Biomech., 17, No. 3, 203-210 (2002).

6. R. Rine, "Management of the pediatric patient with vestibular hypofunction," in: Vestibular Rehabilitation, 3rd ed., FA Davis Comp., Philadelphia (2007), pp. 360-375.

7. S. L. Westcott and P. A. Burtner, "Postural control in children: Implications for pediatric practice," Phys. Occup. Ther. Pediat., 24, Nos. 1/2, 5-55 (2004).

8. R. M. Rine and S. Wiener-Vacher, "Evaluation and treatment of vestibular dysfunction in children," NeuroRehabilitation, 32, No. 3, 507-518 (2013).

9. G. P. Jacobson, D. L. McCaslin, E. G. Piker, et al., "Patterns of abnormality in cVEMP, oVEMP, and caloric tests may provide topological information about vestibular impairment," J. Am. Acad. Audiol., 22, No. 9, 601-611 (2011).

10. E. S. Papathanasiou, T. Murofushi, F. W. Akin, and J. G. Colebatch, "International guidelines for the clinical application of cervical vestibular evoked myogenic potentials: An expert consensus report," Clin. Neurophysiol., 125, No. 4, 658-666 (2014).

11. G. P. Jacobson and D. L. McCaslin, "The vestibular evoked myogenic potential and other sonomotor evoked potentials," in: Auditory Evoked Potentials: Basic Principles and Clinical Application, R. F. Burkard, J. J. Eggermont, and M. Don (eds.), Williams and Wilkins, Lippincott (2007), pp. 572-598

12. M. Valente, "Maturational effects of the vestibular system: a study of rotary chair, computerized dynamic posturography, and vestibular evoked myogenic potentials with children," $J$. Am. Acad. Audiol., 18, No. 6, 461-481 (2007).

13. C. N. Chen, S. J. Wang, C. T. Wang, et al., "Vestibular evoked myogenic potentials in newborns," Audiol. Neurootol., 12, No. 1, 59-63 (2007).

14. P. M. Picciotti, A. Fiorita, W. Di Nardo, et al., "Vestibular evoked myogenic potentials in children," Int. J. Pediat. Otorhinolaryngol., 71, No. 1, 29-33 (2007).

15. Y. H. Young, C. N. Chen, W. S. Hsieh, and S. J. Wang, "Development of vestibular evoked myogenic potentials in early life," Eur. J. Paediat. Neurol., 13, No. 3, 235-239 (2009).

16. S. Erbek, S. S. Erbek, Z. Gokmen, et al., "Clinical application of vestibular evoked myogenic potentials in healthy newborns," Int. J. Pediat. Otorhinolaryngol., 71, No. 8, 11811185 (2007). 
17. T. A. Kelsch, L. A. Schaefer, and C. R. Esquivel, "Vestibular evoked myogenic potentials in young children: Test parameters and normative data," Laryngoscope, 116, No. 6, 895-900 (2006).

18. S. Erbek, Z. Gokmen, S. Ozkiraz, et al., "Vestibular evoked myogenic potentials in preterm infants," Audiol. Neurootol., 14, No. 1, 1-6 (2009).

19. Z. Jafari and S. Asad Malayeri, "The effect of saccular function on static balance ability of profound hearing-impaired children," Int. J. Pediat. Otorhinolaryngol., 75, No. 7, 919-924 (2012).

20. P. M. Picciotti, A. Fiorita, L. Calò, et al., "Vestibular evoked myogenic potentials in children affected by myelomeningocele," Child's Nerv. Syst., 28, No. 10, 1761-1765 (2012).

21. S. J. Wang, C. N. Chen, W. S. Hsieh, and Y. H. Young, "Development of vestibular evoked myogenic potentials in preterm neonates," Audiol. Neurootol., 13, No. 3, 145-152 (2007).

22. G. Zhou, M. A. Kenna, K. Stevens, and G. Licameli, "Assessment of saccular function in children with sensorineural hearing loss," Arch. Otolaryngol. Head Neck Surg., 135, No. 1, 40-44 (2009).

1. K. Kaga, F. Tamai, M. Kodama, and K. Kodama, "Three young adult patients with Pelizaeus-Merzbacher disease who showed only waves I and II in auditory brainstem responses but had good auditory perception," Acta Otolaryngol., 125, No. 9, 1018-1023 (2005).

23. T. Murofushi and K. Kaga, "Neurological application of VEMP recording during infancy and childhood," in: Vestibular Evoked Myogenic Potential: Its Basics and Clinical Applications, Springer (2009), pp. 99-110.

24. ANSI S3.6-2004, Specification for Audiometers, Am. Natl. Standards Institute (2004).

25. J. Shanks and J. Shohet, "Tympanometry in clinical practice," in Handbook of Clinical Audiology, J. Katz et al. (eds.), Williams and Wilkins, Baltimore, Lippincott (2009), pp. 157-188.

26. R. Palisano, P. Rosenbaum, S. Walter, et al., "Development and reliability of a system to classify gross motor function in children with cerebral palsy," Dev. Med. Child Neurol., 39, No. 4, 214-223 (1997).
27. E. Wood and P. Rosenbaum, "The gross motor function classification system for cerebral palsy: A study of reliability and stability over time," Dev. Med. Child Neurol., 42, No. 5, 292-296 (2000).

28. C.H. Su, C.M. Chen, and Y.H. Young, "Differentiating cerebellopontine angle meningioma from schwannoma using caloric testing and vestibular-evoked myogenic potentials," $J$. Neurol. Sci., 335, Nos. 1/2, 155-159 (2013).

29. J .C. Colebatch and G. M. Halrnagyi, "Vestibular evoked potentials in human neck muscles before and after unilateral vestibular deafferentation," Neurology, 42, No. 8, 1635-1636 (1992).

30. H. C. Su, T. W. Huang, Y. H. Young, and P. W. Cheng, "Aging effect on vestibular evoked myogenic potential," Otol. Neurootol., 25, No. 6, 977-980 (2004).

31. I. Krägeloh-Mann and V. Horber, "The role of magnetic resonance imaging in elucidating the pathogenesis of cerebral palsy: a systematic review," Dev. Med. Child Neurol., 49, No. 2, 144-151 (2007).

32. S. M. Scheck, R. N. Boyd, and S. E. Rose, "New insights into the pathology of white matter tracts in cerebral palsy from diffusion magnetic resonance imaging: a systematic review," Dev. Med. Child Neurol., 54, No. 8, 684-696 (2012).

33. S.J .Wang, T.H. Yeh, C.H. Chang, and Y.H. Young, "Consistent latencies of vestibular evoked myogenic potentials," Ear Hear, 29, No. 6, 923-929 (2008).

34. M. S. Shall, "The importance of saccular function to motor development in children with hearing impairments," Int. J. Otolaryngol., 2009, 1-5 (2009).

35. R. O'Reilly, C. Grindle, E. F. Zwicky, and T. Morlet, "Development of the vestibular system and balance function: Differential diagnosis in the pediatric population," Otolaryngol. Clin. North Am., 44, No. 2, 251-271 (2011).

36. Y. R. Burns and M. I. Bullock, "Comparison of abilities of preterm and maturely born children at 5 years of age," Aust. Paediat. J., 21, No. 1, 31-38 (1985).

37. J. G. Colebatch and J. C. Rothwell, "Motor unit excitability changes mediating vestibulo-collic reflexes in the sternocleidomastoid muscle," Clin. Neurophysiol., 115, No. 11, 2567-2573 (2004). 